\title{
CD274 Gene
}

National Cancer Institute

\section{Source}

National Cancer Institute. CD274 Gene. NCI Thesaurus. Code C96022.

This gene is involved in T cell activation and proliferation. 